\title{
The Changing Landscape of Muslim-Jewish Relations in the Modern Middle East and North Africa
}

\author{
D.J. Schroeter
}

Mr. Hatchwell, or Si Hatweel as he was also known to the local residents, was one of the few remaining Jews who inhabited the elite casbah quarter in the Moroccan town of Essaouira (or Mogador as it was formerly called by Europeans) in 1981. In thinking about how changing patterns of public space in the nineteenth century Middle East and North Africa (MENA) affected and transformed Muslim-Jewish relations, I am reminded of my conversations with him that year. I recall one day strolling with him in Essaouira, where he proudly showed me the places of importance to him-lieux de mémoire-a nail on the wall where the Paquet steamship line of Marseilles once posted their schedules, the former foreign consulates that were located in the casbah quarter, the sign commemorating the visit in $\mathbf{1 8 8 4}$ of the intrepid Father Charles de Foucauld, whose account of his travels in Morocco disguised as a native rabbi remain the most celebrated of the pre-colonial period. ${ }^{1}$ He bumped into an elderly Muslim similar in age, precipitating a warm embrace and a few dance steps, almost like a reunion between two octogenarians, Muslim and Jew, both respected members of the Chambre de Commerce.

Jacob Hatchwell came from a family that moved from Marrakesh to Essaouira in the late nineteenth century, joined the elite Jewish merchants who lived in the casbah, and engaged in an import-export trade with Manchester, London, and Hamburg, the latter after the expansion of German commercial interests on the southern Atlantic coast of Morocco in the late nineteenth and early twentieth century. ${ }^{2}$ Essaouira was already in decline as an international

1 Not only is Charles de Foucauld an iconic figure in French colonial literature, but stories about him, and his guide Mardochée Aby Serour, are remembered by Muslims in the south of Morocco where they traveled. See Aomar Boum, Memories of Absence: How Muslims Remember Jews in Morocco (Stanford, CA: Stanford University Press, 2013), 18-28.

2 On German expansion in Morocco, see Pierre Guillen, L'Allemagne et le Maroc de 1870 à 1905 (Paris: Presses universitaires de France, 1967). With the exponential growth of German ships 
port of trade when members of the family emigrated from Morocco, opening up stores or import-export firms in various in locales: London, Brighton, Alexandria, and Cairo, or set up business in more prosperous locations in Morocco, especially Casablanca and Safi. Several Hatchwells ventured to South America following in the wake of the rubber boom, and settled in Iquitos in the Peruvian Amazon. Jacob's brother David was among the few remaining Jews in Iquitos; many left with the declining rubber economy or had intermarried and assimilated into the Amazonian Indian population. The family stayed connected through visits to Essaouira and a correspondence back and forth between three continents in Judeo-Arabic, French, English, and Spanish. ${ }^{3}$

At the time of my encounter, Mr. Hatchwell was the owner of the rather modest Hotel Beau Rivage, formerly managed by his late wife, above the popular Café de France located in the large Place du Chayla (now named Place Moulay Hassan), which is accessed from the port. ${ }^{4}$ At the time I lived in Essaouira in 1981, Mr. Hatchwell's main occupation seemed to have been acting as the agent for the Pullman coach company, the "deluxe" sleeper coach line of buses that traveled overnight between Agadir and Casablanca, making a stop in Essaouira at about $11 \mathrm{pm}$. Four places were reserved for Essaouira, and to obtain a ticket one was required to pay a visit to Mr. Hatchwell in his house in the casbah, where he received customers in his "European salon," which boasted an upright piano and a portrait of Queen Victoria hanging on the wall. ${ }^{5}$ On one occasion, I met his elderly sister there, who babbled in the incoherent though fluent English that she had learned at the English girls' school (long since closed) attended by Essaouira's Jewish elite.

calling at the port of Essaouira, the Deutsche Seewar Company of Hamburg was authorized to build and operate a meteorological observatory in the harbor of Essaouira. Le Guido-le magazine d'Essaouira, no. $3^{2}$ (2011), 5-7.

3 Archives of the Hatchwell family of Essaouira are found in the library of the Centre de la Culture Judéo-Marocaine (Brussels) (http://www.judaisme-marocain.org/); it contains both personal and business correspondence and documents. On Moroccan Jewish emigration to the Amazon, see Susan Gilson Miller, "Kippur on the Amazon: Jewish Emigration from Northern Morocco in the Late Nineteenth Century," in Harvey E. Goldberg (ed.), Sephardi and Middle Eastern Jewries, History and Culture in the Modern Era (Bloomington: Indiana University Press, 1996), 190-209. On Jews of Iquitos, see Ariel Segal, Jews of the Amazon: SelfExile in Earthly Paradise (Philadelphia: Jewish Publication Society, 1999).

4 See the description in the memoir by David Bensoussan, Le fils de Mogador (Montreal: Les Éditions Du Lys, 2002), 77-79.

5 See Daniel J. Schroeter, Merchants of Essaouira:Urban Society and Imperialism in Southwestern Morocco, 1844-1886 (Cambridge: Cambridge University Press, 1988), 58-59. 
Most of the Jews of Essaouira had lived in the overcrowded mellah, the Jewish quarter built in 1808 where no Muslims lived. ${ }^{6}$ The casbah, by contrast, always housed both Muslim and Jews of the elite, foreign merchants and consuls, and government officials. The Attias synagogue in the casbah, built in the late nineteenth century, imported woodwork from Manchester, ${ }^{7}$ while homes of the affluent were embellished by furniture and other English accoutrements, as was the case in the Hatchwell household. ${ }^{8}$ Among the Jewish elite, English was often spoken and a number of English expressions were a part of everyday Judeo-Arabic speech in Cultural affinities to England lingered in the twentieth century, especially among the elite, but French influence became more pronounced in the Protectorate period largely owing to the Alliance Israélite Universelle school (where Mr. Hatchwell studied), though Arabic remained the dominant language of the Jewish masses of the mellah-Jewish space, where nonetheless the elite Jews of the casbah rarely, if ever set foot. Thus Mr. Hatchwell's walking tour did not include the mellah, which in 1981 was the poorest, most overcrowded and dilapidated quarter of the town. Only a few Jews still resided there: a plumber and his family, and a jeweler. One distillery of mahya, the ubiquitous eau de vie once produced by Jews throughout Morocco, remained in the mellah, where there was frequently a long queue of Muslims waiting their turn to purchase a supply. Jews had long provided Muslims with forbidden alcoholic beverages, and it was a reason for Muslims to venture into Jewish space, a common phenomenon in other places in MENA as well. Yet crossing ethno-religious boundaries into Jewish space for forbidden fruits could also be a source of friction. In 1906, when rural revolts were rampant in Morocco and when foreign intervention had exacerbated internal divisions and interreligious tensions, Anflus, a rebellious local tribal leader, invaded Essaouira with his followers and expelled Jews from the medina, the popular Muslim quarter that they had begun to inhabit. During Anflus' brief occupation of the town and before order was restored by central authorities, Jews were

6 In an 1807 decree, Mawlay Sulayman ordered Jews in a number of cities to sell their homes and to move to mellahs within boundaries to be demarcated. In Essaouira, however, some elite Jews were allowed to live in the casbah quarter alongside Muslims and foreigners. Daniel J. Schroeter, The Sultan's Jew: Morocco and the Sephardi World (Stanford, CA: Stanford University Press, 2002), 90-93.

7 Dilapidated and no longer in use, there are plans to restore the Attias synagogue and convert it into a Jewish museum. See Le Guido-Magazine d'Essaouira no. 38 (2013) 5-8.

8 On transformations of domestic space and European furnishings in the nineteenth-century Ottoman Empire, see Donald Quataert, The Ottoman Empire, 1700-1922 (Cambridge: Cambridge University Press, 2000), 151-154. 
forced to remove their shoes when walking past a mosque or Muslim shrine, compelled to release their slaves, and mahya distilleries were shut down. As the story goes, some of the authorities thought it better that the Jews should remain outside the medina, but the mahya distilleries were quickly restored and back in operation. ${ }^{9}$

With the partial exception of Tangier, Essaouira was in some ways unique to Morocco: it was a small cosmopolitan town before European influence had begun to significantly influence Moroccan society. It had a rather special elite connection to England and an openness and conviviality existed between ethnic and religious groups and between Europeans and Moroccans in an era when foreigners were all but banned from the major inland cities of Marrakesh, Fez, and Meknes. And yet, though Essaouira was an atypical case, there are many aspects of this vignette that can be seen as a microcosm reflecting the transformation of the public sphere, one in which new encounters and new spaces redefined patterns of Muslim-Jewish relations, not only in Morocco, but in many parts of MENA.

There is another reason to begin the discussion with a story from the recent past. By studying Jews that remained in the Islamic world after the mass emigration, we shift the focus from the narrative of failed integration and departure that dominates most scholarship on Muslim-Jewish relations in the modern period. The study of Muslim-Jewish relations has been shaped by the traumatic mass emigration from the societies in which Jews once lived. The incontrovertible fact that the majority of Jews in MENA departed during the period from 1948 to the early 1960 s and the virtual absence of Jewish communities from MENA outside Israel seems to provide powerful evidence of the impossibility of Jews integrating into the countries in which they lived. This has been explained in two ways that essentially reflect the Israeli-Palestinian political divide. One side argues that the Islamic world provided a haven for Jews, and that the peaceful coexistence that prevailed through the Middle Ages was undermined by colonialism and Zionism. Colonialism, by its system of divide and rule, by favoring Jews over Muslims, drew Jews over to the side of the colonial occupiers, while Zionism, in the age of decolonization completed the process of severing Jews from their native lands. The other side emphasizes a constant state of conflict throughout history and hardly differentiates the modern from the

9 AIU (Archives of the Alliance Israélite Universelle)/Maroc XXXIII.E.582, 2 September 1906, 9 September 1906, Benchimol; al-Maghrib al-Aqsa (15 September 1906). The occupation of Essaouira by Anflus remains in the historical memory of the Jews. See Salomon Haï Knafo and Asher Knafo, La vie juive a Mogador (Ashdod: Ot Brit Kodech, 2009), 137-138. 
medieval period. This side presents non-Muslims as living in a state of oppression, dubbed "dhimmitude," a neologism that has gained much currency in recent years; it thereby implies a primordial condition that is rooted in the origins of Islam itself. ${ }^{10}$ The emerging Arab states, in this paradigm, failed to develop civil societies to which non-Muslims belonged, because they remained "Islamic" to the core. Thus it is argued that Jews left because of Islam and the appeal of a Jewish state that would empower them. The years of colonialism and decolonization are considered unimportant except insofar as they helped exacerbate pre-existing tensions and precipitated a final rupture by removing Jews from their dhimmi condition, exposing their new status as minorities, and introducing European style anti-Semitism into MENA. ${ }^{11}$

While these stances are oppositional, they share a sense of the inevitability of mass departure; both emphasize conflict and exclusionary categories and identities that developed in Middle East and North African societies in modern times; the first sees the divisions as entirely a product of the modern era, while the other assumes that the divide was always present. Both approaches are teleological, predicated on the belief in failure, or the impossibility of MuslimJewish coexistence either because of internal or external circumstances. Consequently, scholarship has all but ignored new patterns of coexistence, modern

10 The idea of the oppression of Jews and non-Muslim minorities, and the notion of "dhimmitude" has been influenced by the many publications of Bat Ye'or, The dhimmi: Jews and Christians under Islam (Rutherford, NJ: Fairleigh Dickinson University Press; London: Associated University Presses, 1985; originally published in French in 1980); Islam and Dhimmitude: Where Civilizations Collide (Cranbury, NJ: Fairleigh Dickinson University Press/Associated University Presses and Lancaster, UK: Gazelle Book Services Ltd., 2002).

11 This latter approach to the understanding of Jews in the Islamic world is found in the last chapter of the often cited book by Bernard Lewis, The Jews of Islam (Princeton, NJ: Princeton University Press, 1984), 154-191; also in idem, Semites and Anti-Semites (New York: Norton, 1986). A recent example of a book that follows this approach is the voluminous and richly documented study by Georges Bensoussan, Juifs en pays arabes: le grand déracinement, 1850-1975 (Paris: Tallandier, 2012). For a critical evaluation of the historiography, see Mark R. Cohen, Under Crescent and Cross: The Jews in the Middle Ages (Princeton, NJ: Princeton University Press, 1994), 3-14; Daniel J. Schroeter, "From Sephardi To Oriental: The 'Decline' Theory of Jewish Civilization in The Middle East and North Africa," in Richard Cohen and Jeremy Cohen (eds.), The Jewish Contribution to Civilization: Reassessing an Idea (Oxford: Littman Library of Jewish Civilization, 2007), 125-148; Joel Beinin, The Dispersion of Egyptian Jewry: Culture, Politics, and the Formation of a Modern Diaspora (Berkeley: University of California Press, 1998), 14-19; Orit Bashkin, New Babylonians: A History ofJews in Modern Iraq (Stanford, CA: Stanford University Press, 2012), 9-10. 
developments that enabled new encounters and a common ground to develop between Muslims and Jews in the period before the mass exodus that began in the late 1940s.

Much of the focus on the Jews of the modern Middle East and North Africa has been on the question of legal status, which is fundamental for understanding changes in the position of Jews and minorities in predominately Muslim societies. The Ottoman Empire, under pressure from foreign powers and an internal impetus to preserve the empire, undertook reforms to eliminate the traditional dhimmi status of non-Muslims. From the Hatt-i Şerif of Gülhane (1839) to the Hatt-i Humayun (1856), the Tanzimat reforms effectively transformed non-Muslims from protégés of the Islamic state to Ottoman citizens with civil rights. Yet it was still an empire composed of many ethno-religious groups and the state maintained its system of separate communities, now reorganized into millets that would be closely kept under the surveillance of the Ottoman Porte. Egypt, still nominally a part of the Ottoman Empire but ruled by an independent dynasty, enacted a series of reforms that eliminated dhimmi status; thus some of the inequalities that existed during the time of Muhammad 'Alī were removed and then dhimmi status was abrogated and in 1882 nonMuslims were granted full civil equality. ${ }^{12}$ The condition of MENA Jews came under the scrutiny of the European powers and their emancipated Jewish citizens and organizations, notably the Alliance Israélite Universelle (founded in 1860); both found an important goal in the protection of the Jews and their "emancipation," though each for its own, sometimes, overlapping purposes. ${ }^{13}$ Islamic law, degrading to non-Muslims, was seen as responsible for keeping Jews in their abject state.

Following the Hatt-i Humayun, the British and French put pressure on the Bey of the Husaynid dynasty of Tunisia, nominally part of the Ottoman Empire, to implement the Tanzimat reforms. The execution of Batto Sfez, accused of

12 For a survey of the changing legal status of the Jews of MENA, see Norman A. Stillman, The Jews of Arab Lands in Modern Times (Philadelphia: Jewish Publication Society, 1991), 8-18; Bruce Masters, Christians and Jews in the Ottoman Arab World: The Roots of Sectarianism (Cambridge: Cambridge University Press, 2001), 134-141.

13 There is a considerable literature on the Alliance Israélite Universelle and its impact in MENA. See especially Aron Rodrigue, Jews and Muslims: Images of Sephardi and Eastern Jewries in Modern Times (Seattle: University of Washington Press, 2003); idem, French Jews, Turkish Jews: The Alliance Israelite Universelle and the Politics of Jewish Schooling in Turkey 1860-1925 (Bloomington: Indiana University Press, 1990); Michael M. Laskier, The Alliance Israélite Universelle and the Jewish Communities of Morocco, 1862-1962 (Albany: State University of New York Press, 1983). 
blaspheming Islam, provided the opportunity: under threat of the French fleet bombarding Tunis, Muhammad Bey issued the so-called "fundamental pact" ('ahd al-amān, literally, "the pact of security") which embodied the principles of the Ottoman reform movement as they related to religious minorities, removed civil inequalities that effected the Jews (here we should be reminded that in the Maghrib, with the disappearance of indigenous Christians in the Middle Ages, the only dhimmis were Jews; Christians were regarded as foreign). These changes were stipulated in the Constitution of 1861, which in effect formally ended the laws that defined the legal status of Jews as dhimmis. $^{14}$

Outside the Ottoman Empire, in Morocco and Iran, the rulers of these independent dynasties also came under increasing foreign pressures to "emancipate" their Jews. In these cases, it was the Anglo-Jewish leader and global advocate of emancipation, Moses Montefiore, who campaigned and obtained in 1864 and 1865, respectively, imperial decrees that guaranteed that Jews would be treated with justice..$^{15}$ In the case of Morocco, the sultan made it clear that he was only reiterating the law that already guaranteed the Jews just treatment, ${ }^{16}$ and dhimmi status remained. The French Protectorate, established in Morocco in 1912, was legitimized by the idea of preserving native institutions; the Protectorate maintained the monarchy, an Islamic ruler with Muslim and Jewish subjects. While the civil inequalities associated with dhimmi status were eliminated, Jews remained indigenous dhimmi subjects of the sultan, now under the supposed tutelage of the French. ${ }^{17}$

The end of the Ottoman Empire brought colonial rule and eventually independence to much of the Arabic speaking world, which was divided into new nation states. In most places Jews-no longer dhimmis or members of a millet

14 Paul Sebag, Histoire des Juifs de Tunisie: des origins à nos jours (Paris: L’Harmattan, 1991), 116-121; Yaron Tsur, "Ahd al-Amān," EJIW, 1:93-94.

15 Mohammed Kenbib, Juifs et Musulmans au Maroc, 1859-1948 (Rabat: Université Mohammed v, Publications de la Faculté des Lettres et des Sciences Humaines, 1994), 123ff.; Abigail Green, Moses Montefiore:Jewish Liberator, Imperial Hero (Cambridge, MA: Belknap Press of Harvard University Press, 2010), 300-319, 365-367; Michel Abitbol, Le passé d'une discorde: Juifs et Arabes depuis le viie siècle (Paris: Perrin, 1999), 168-172; Daniel Tsadik, Between Foreigners and Shicis: Nineteenth-Century Iran and its Jewish Minority (Stanford, CA: Stanford University Press, 2007), 57-59.

16 Aḥmad b. Khālid al-Nāșirī, Kitāb al-Istiqșā li-akhbār duwal al-Maghrib al-aqșā (Casablanca: Dār al-Kitāb, 1956), 9:113.

17 Daniel J. Schroeter and Joseph Chetrit, "Emancipation and its Discontents: Jews at the Formative Period of Colonial Rule in Morocco," Jewish Social Studies 13, 1 (2006): 170-206. 
with well-defined boundaries - became minorities, often with tenuous rights and an uncertain future. Arab nationalism and nationalist politics appealed to a very few, with the major exception of Iraq, and most left en masse when the opportunity was presented.

The change in legal status of Jews, from dhimmis who were discriminated against to unassimilable minorities, is the focus of many studies on Jews in the modern MENA and offers an explanation of important changes in the position of Jews in MENA society. Yet the emphasis on the Jews' status-legal, political, social—has tended to dominate discussions with the result of precluding important questions about how Jews interacted with non-Jews in the emerging public sphere that was reshaping the landscape of the modern MENA.

To think about the emerging public sphere of Muslim-Jewish interaction in the modern MENA, it is important to consider what constituted those spaces, both public and private, where Muslims and Jews interacted in the premodern period. In urban structures, Islamic law distinguished between the private, residential sector, represented spatially by residential quarters with alleyways and culs de sac, and public space, with wide open thoroughfares where suqs were located. ${ }^{18}$ Throughout the cities of MENA, including Tunis, Cairo, Damascus, Aleppo, and Baghdad, Jews were concentrated in specific residential quarters, and in the case of Morocco, in some locales it was compulsory for Jews to live in Jewish quarters, which became known as mellahs. ${ }^{19}$ These quarters thus might be defined as Jewish space, where family and religious life was located and where ethno-religious boundaries were conceptually constructed. It was, above all, the market place, the suq, in both urban and rural settings that functioned as a shared public space where Muslims and Jews intermingled. ${ }^{20}$ The move

18 Besim Selim Hakim, Arabic-Islamic Cities: Building and Planning Principles (London: KPI, 1986), 63; André Raymond, Grandes villes arabes à l'époque ottomane (Paris: Sindbad, 1985), 172-174.

19 See Daniel J. Schroeter, "Le quartier juif et la cité islamique," in Shmuel Trigano (ed.), Le monde sépharade: histoire et civilisation, 2 vols. (Paris: Éditions du Seuil, 2006), 2:565583; idem, "The Jewish Quarter and the Moroccan City," in George K. Zucker and Yedida K. Stillman (eds.), New Horizons in Sephardic Studies (Albany: State University of New York Press, 1993), 67-81. For a focus on minority space in the Mediterranean city and its historiography, see the introduction by Susan Gilson Miller, in Susan Gilson Miller and Mauro Bertagnin (eds.), The Architecture and Memory of the Minority Quarter in the Muslim Mediterranean City (Cambridge, MA: The Aga Khan Program at the Harvard University Graduate School of Design, 2010), 10-33.

20 Clifford Geertz, drawing from his research on Sefrou in Morocco, focuses his attention on the suq as an institution that characterizes mena as a whole. See "Suq: The Bazaar 
from the interiority of the home and neighborhood to the marketplace marked a quotidian spatial passage from the private to the public. It is also significant that Muslim religious endowments (habus in the Maghrib, waqf in the Middle East), which one might think of as the quintessential Muslim space, were often leased for commercial uses as funduqs, shops, and coffeehouses and as such were an important domain of Muslim-Jewish interactions. ${ }^{21}$ In Morocco, Jews were tenants of habus properties in places that were outside the Jewish quarters in the marketplaces and commercial "public" districts of cities. ${ }^{22}$ Rural markets as well functioned as a space where Muslims and Jews intermingled and exchanged goods and services. In Morocco, shared sacred spaces, or intermingling during the times of pilgrimages (mawsims or hillulot), also became places of commercial exchange, thus complicating any notion of a sharp dichotomy between the sacred and the profane. Jewish peddlers and traders were woven into the fabric of the rural economy in many parts of MENA, ${ }^{23}$ as expressed in a Moroccan proverb "A suq (market) without Jews ... is like bread without salt." ${ }^{24}$

Economy in Sefrou," in Clifford Geertz, Hildred Geertz, and Lawrence Rosen, Meaning and Order in Moroccan Society (Cambridge: Cambridge University Press, 1979), 123. See also Eugen Wirth, "Villes islamiques, villes orientales? Une problematique face au changement," in Abdelwahab Bouhdiba and Dominique Chevalier (eds.), La ville arabe dans l'Islam (Tunis: Université de Tunis, Centre d'études et de recherches économiques et sociales, 1982), 198-226.

21 For an argument that proposes the waqf as a key institution that constituted a public sphere, see Haim Gerber, "The Public Sphere and Civil Society in the Ottoman Empire," in Miriam Hoexter, Shmuel N. Eisenstadt, Nehemia Levtzion (eds.), The Public Sphere in Muslim Societies (Albany: State University of New York Press, 2002), 75-77.

22 The voluminous registers and archives of the habus administration of the French protectorate were found in the Bibliothèque Générale et Archives, Rabat, accessed in 1980-1981. For Essaouira, numerous shops in the markets were leased to Jews. See also "Report on Leasehold Makhzen and Habous Properties held in British Hands," 10 May 1918, National Archives of the UK, FO 835/164.

23 Boum, Memories of Absence, 29-55; "Morocco in the Nineteenth Century," in Mark R. Cohen and Abraham L. Udovitch (eds.), Jews Among Arabs: Contacts and Boundaries (Princeton, NJ: Darwin Press, 1989), 113-140; on Jerba and its vicinity, see Abraham L. Udovitch and Lucette Valensi, The Last Arab Jews: The Communities ofJerba, Tunisia (Chur, Switzerland: Harwood Academic, 1984), 100-106; on Muslim-Jewish relations in rural Yemen, see BatZion Eraqi-Klorman, "Yemen: Religion, Magic, and Jews," Proceedings of the Seminar for Arabian Studies 39 (2009): 125-134; on Libya, Harvey E. Goldberg, Jewish Life in Muslim Libya: Rivals and Relatives (Chicago: University of Chicago Press, 1990), 68-81. 
Language is another aspect of this shared space in the marketplace. While almost everywhere, Jews historically spoke their own languages, or dialects of the dominant languages (Judeo-Arabic, Judeo-Spanish, and so forth) within Jewish or communal spaces, in the marketplaces, Jews, especially men, communicated in the vernaculars of their surroundings, yet were still distinguishable by their accents or sartorial customs, especially headgear. Jews were thus often bilingual or multilingual in the often monolingual environments in which they lived. ${ }^{25}$

While the demarcation of private and public space was expressed spatially by divisions between residential Jewish quarters and the marketplace, this did not imply a rigid separation between the private, communal space of the Jewish quarter and the public sections of the city. Indeed the very concept of insulated and largely self-contained dhimmi communities is belied by the many ways in which communal boundaries were constantly negotiated, transcended or transgressed in everyday life in many spaces besides the marketplace. ${ }^{26}$ Contrary to common assumptions about the legal separation of dhimmis, Jews often went to Muslim courts. ${ }^{27}$ In many places, Muslims frequently shopped, purchased meat from kosher butchers, bought or consumed alcohol in Jewish quarters. In most of MENA as well, though there was a tendency for dhimmis to concentrate in ethno-religious neighborhoods, the boundaries were permeable and Muslims would purchase, lease or reside in homes in the Jewish quarters, as evidence from eighteenth- and nineteenth-century Syria shows. ${ }^{28}$

25 On dress, language, and distinguishing symbols of identity, see Udovitch and Valesi, The Last Arab Jews, 24-29.

26 This has been clearly documented and analyzed for Marrakesh in Emily Gottreich, The Mellah of Marrakesh:Jewish and Muslim Space in Morocco's Red City (Bloomington: Indiana University Press, 2007).

27 Studies of shari'a court records and government archives demonstrate the extent to which Jews often sought justice in Muslim courts. See Amnon Cohen, Jewish Life under Islam: Jerusalem in the Sixteenth Century (Cambridge, MA: Harvard University Press, 1984);Jessica Marglin, "In the Courts of the Nations: Jews, Muslims, and Legal Pluralism in NineteenthCentury Morocco" (Ph.D. diss., Princeton University, 2013).

28 Najwa al-Qattan, "Litigants and Neighbors: The Communal Topography of Ottoman Damascus," Comparative Studies in Society and History 44 (2002): 511-533. For the Middle East generally, see Masters, Christians and Jews, 31-37; Antoine Abdel Nour, "Habitat et structures sociales à Alep aux XVII ${ }^{\mathrm{e}}$ et XVIII ${ }^{\mathrm{e}}$ siècles," La ville arabe dans l'Islam, 86-89; Abraham Marcus, The Middle East on the Eve of Modernity: Aleppo in the Eighteenth Century (New York: Columbia University Press, 1989), 44. 
Coffeehouses, widespread throughout the Ottoman Empire from the sixteenth century, also constituted public space, and could be located throughout the city and, as in the case of Damascus, could be found in residential districts and markets, in both intra- and extra-mural quarters. ${ }^{29}$ Coffeehouses became the unrivaled space of male social life and leisure, where people of various social backgrounds gathered for conversation, news, games, and entertainment. As primarily a space of Muslim male sociability, we cannot know to what extent Muslims and non-Muslims intermingled in coffeehouses. Yet it is well known in many places in MENA that Jewish musicians performed in coffeehouses to diverse crowds. If coffeehouses were the primary public space of male sociability, bathhouses (hammam) provided women with gendered public space. ${ }^{30}$ Outside the private space of the home, Muslim and nonMuslim men and women, either in separate facilities or at separate times, used the bathhouses as public spaces of socialization. There was, perhaps, concern about how undressed Muslims and Jews might be distinguished; thus sometimes they were given different towels or robes with particular markings. $^{31}$

The change in status of Jews, from dhimmis to Ottoman or colonial subjects or citizens, or to minorities in the nation states of MENA did not necessarily mean that premodern forms of social relations and spatial structures were replaced with a secular society where Muslims and Jews interacted in a commonly shared public sphere. Yet new kinds of relations nevertheless developed alongside the old and interacted with older types of Muslim-Jewish encounters. Port cities especially were conduits of change, bridgeheads of modernity that led to the development of new kinds of common grounds. To take the example of commerce, it was not so much that the suq was displaced but new institutions and forms of interaction and exchange between Muslims and Jews developed alongside the old. These included chambers of commerce, places of exchange outside the suq, grocery stores, pharmacies, hotels, and so forth. In Cairo and Baghdad, for example, Jews were often entrepreneurs in new, more

29 James Grehan, Everyday Life and Consumer Culture in 18th-Century Damascus (Seattle: University of Washington Press, 2007), 140-146.

30 Ralph S. Hattox, Coffee and Coffeehouses: The Origins of a Social Beverage in the Medieval Near East (Seattle: University of Washington Press, 1985), 94-98; Quataert, The Ottoman Empire, 158-159; on Aleppo, see Marcus, The Middle East on the Eve, 43-44, 231-235; on Tunis, see Julia A. Clancy-Smith, Mediterraneans: North Africa and Europe in an Age of Migration, c. 1800-1900 (Berkeley: University of California Press, 2011), 138-140.

31 Amnon Cohen, Jewish Life under Islam: Jerusalem in the Sixteenth Century (Cambridge, MA: Harvard University Press, 1984), 73, 138-139; Marcus, The Middle East on the Eve, 41-42. 
"modern" commercial sectors, from furniture and grocery stores to European style department stores. ${ }^{32}$ Jews were innovators also in the development of modern banks and financial institutions in the key cities of MENA: Tangier, Cairo, Alexandria, Beirut, Aleppo, and Baghdad. Because of their extensive networks with Europe, Jews were owners and agents for steamship and shipping lines, and were important in the development of railroads and transportation, and in general were instrumental in the introduction of modern industry and technology. ${ }^{33}$

New commercial practices entailed new patterns of consumption and brought together Muslims and Jews on common ground in new public spaces. Modern shops were to be found also in developing public spaces, as cities expanded extra muros, with new neighborhoods outside the traditional old city walls, the nouvelle ville in French colonial terminology was distinct from the medina. Outside the walls or traditional quarters, with shops, wider avenues with spacious apartments, cafés, clubs and associations, theaters, cinemas, music halls, sports stadiums, the promenade and beach, Muslim and Jews interacted in public spaces in ways unimaginable in the past. Families strolled in parks and the wide boulevards, where new fashions and hairstyles were displayed. ${ }^{34}$ New modes of interaction were reflected in changing residential patterns, and as Jews began to move to Muslim quarters, the result was both peaceful coexistence and increased tensions and violence as the older patterns were disrupted. ${ }^{35}$ At the same time that the embourgeoisement of a growing sector of society caused Muslims, Christians, and Jews to intermingle in new ways

32 On the transformation of Cairo's commercial district and the development of department stores, see Nancy Y. Reynolds, A City Consumed: Urban Commerce, the Cairo Fire, and the Politics of Decolonization in Egypt (Stanford, CA: Stanford University Press, 2012).

33 Gudrun Krämer, The Jews in Modern Egypt, 1915-1952 (Seattle: University of Washington Press, 1989), 39-41; Beinin, The Dispersion of Egyptian Jewry, 44-49; Michael Menachem Laskier and Reeva Spector Simon, "Economic Life," in The Jews of the Middle East and North Africa in Modern Times (New York: Columbia University Press, 2003), 41-43; and Reeva Spector Simon, "Iraq," in The Jews in the Middle East, $362-363$; Reeva Spector Simon, "Banking," EJIW, 1:335-337.

34 Sarah Abrevaya Stein, Making Jews Modern: The Yiddish and Ladino Press in the Russian and Ottoman Empires (Bloomington: Indiana University Press, 2004), 181-183.

35 For Tunis in the nineteenth century, see Abdelhamid Larguèche, "La communauté juive de Tunis à l'époque husseïnite: unité, contrastes et relations inter-communautaires," in Histoire communautaire, histoire plurielle: la communauté juive de Tunisie: actes du colloque de Tunis organisé les 25-26-27 février 1998 à la Faculté de la Manouba (Tunis: Centre de Publication Universitaire, 1999), 176-177. 
as the new social class often cut across religious and ethnic divisions, ordinary Jews and Muslims maintained their separate communal space. In some places new inter-confessional tensions caused Jews to concentrate even more in mainly Jewish quarters, ${ }^{36}$ intensifying the separation of poor Jews from Muslims, and Jewish quarters became increasingly overcrowded slums, not only reinforcing ethno-religious boundaries, but also reflecting the widening division between social classes in each respective religious community, as Muslim, Jewish, and Christians of the growing middle class resided in the modern, bourgeois, more cosmopolitan European neighborhoods. And yet, the old Jewish quarter remained an important symbolic marker of Jewish space. As has been observed in literature on Jewish Baghdad, "the city's 'Jewishness,' so to speak, is a function of its cosmopolitan character, which depends both upon an implicit recognition of the city's intercultural essence, on the one hand, and on the performance of communal identity through linguistic and spatial boundaries, on the other,"37 an observation that could also be applied to Cairo, Tunis, and other major cities in MENA.

Even in places where ethnic tensions and intra-communal divisions were accentuated and expressed by reinforcing spatial segregation, modernity in its many forms increased encounters between Muslims and Jews in shared public spaces. Coffeehouses, for example, already numerous in MENA in the premodern period, continued to grow in many places, while with the increasing degree of foreign influence and colonialism, taverns owned or run by nonMuslims served alcoholic beverages to a mixed clientele. ${ }^{38}$ The development of this secular common ground - spaces of sociability, and the leisure activities associated with them - at times provoked the reproach of both Muslim and Jewish religious leaders, who believed that it was causing a laxity in morality and religious practice. ${ }^{39}$ Yet even in the disapprobation of religious leaders,

36 Abdel-Nour, "Habitat," 88-89.

37 Lital Levy, "Self and the City: Literary Representations of Jewish Baghdad," Prooftexts, 26, no. 1-2, (2006): 165 .

38 Clancy-Smith, Mediterraneans, 138-140; Zvi Zohar, Rabbinic Creativity in the Modern Middle East (London: Bloomsbury, 2013), 259-261.

39 On rabbinical criticism of Jews engaged in leisure activity and laxity in religious practice, see Zohar, Rabbinic Creativity, 116-117, 233-268; see Matthias B. Lehmann, Ladino Rabbinic Literature and Ottoman Sephardic Culture (Bloomington: Indiana University Press, 2005), 82-88; on nineteenth- and early twentieth-century Baghdad, see Shlomo Deshen, "Baghdad Jewry in Late Ottoman Times: The Emergence of Social Classes and of Secularization," AJs Review 19, 1 (1994): 37-40; on Syria, see Walter P. Zenner, "Jews in Late Ottoman Syria: Community, Family and Religion," in Shlomo Deshen and Walter P. Zenner (eds.), Jews 
whose authority was growing weaker in this period, we see the emergence of new patterns of public discourse. Theories on the emergence of a civil society and the Habermasian notion of bourgeois public sphere privilege the development of secularism produced by the modern (European) state that would enable access to all individuals, regardless of religion. Secularism was indeed a factor in the new public sphere in MENA, but for the vast majority of people, secularization coexisted with the continuation of religious observance and ethno-religious ties. Indeed, one can talk about a public sphere in which Muslims and non-Muslims participated, without the corollary of the modern secular state as it developed in the European setting. ${ }^{40}$ Indeed, one can better understand the new shared public spaces, if one eschews the more linear or hegemonic definition of Western modernity, and assumes rather that their were "multiple modernities," or a variety of trajectories in which to understand the development of modernity in MENA. ${ }^{41}$

Language also reflected the dialogue between the inner, communal space and the wider public, and the strategic positioning of Jews in the dominant society. ${ }^{42}$ Jewish languages or dialects of the dominant languages (Judeo-Arabic, Judeo-Spanish, and so forth) increasingly coexisted with European languages, the latter linked to European networks of trade and eventually, empires. The communal languages of the Jews from the mid-nineteenth century also became a part of a new secular public sphere, expressed especially in the proliferation and dissemination of newspapers in Judeo-Spanish and Judeo-Arabic; Jews in MENA also participated in the Hebrew revival movement, by publishing articles in Haskalah newspapers in Europe. ${ }^{43}$ Though it varied from place to place,

among Muslims: Communities in the Precolonial Middle East (London: Macmillan, 1996), 180-184; on rabbinic criticism of Jews frequenting Muslim owned coffeehouses in Tripoli, see Harvey E. Goldberg and Claudio G. Segre, "Holding on to Both Ends: Religious Continuity and Change in the Libya Jewish Community, 1860-1949," Maghreb Review 14, 3-4 (1989): 170 .

40 For a critical discussion of theories about the public sphere in Muslim societies, see the introduction in Armando Salvatore and Mark LeVine (eds.), Religion, Social Practice, and Contested Hegemonies: Reconstructing the Public Sphere in Muslim Majority Societies (New York: Palgrave MacMillan, 2005), 1-17; Dale F. Eickelman and Armando Salvatore, "The Public Sphere and Muslim Identities," European Journal of Sociology 43 (2002): 92-115.

S.N. Eisenstadt, "Multiple Modernities," Daedalus 129, 1 (2000): 1-29; Dale F. Eickelman, "Islam and the Languages of Modernity," Daedalus 129, 1 (2000): 119-135.

42 Joëlle Bahloul, The Architecture of Memory:A Jewish-Muslim Household in Colonial Algeria, 1937-1962 (Cambridge: Cambridge University Press, 1996): 87-88.

43 Stein, Making Jews Modern: The Yiddish and Ladino Press in the Russian and Ottoman Empires (Bloomington: Indiana University Press, 2004); Lehmann, Ladino Rabbinic Lit- 
French became the language of modernity for many Jews, ${ }^{44}$ especially because of the network of schools established by the Alliance Israélite Universelle; after its first school was opened in Morocco in 1862 they expanded throughout the Mediterranean. ${ }^{45}$ Alliance schools, which promoted French language and culture, proliferated throughout MENA; its teachers often came from one part of the Mediterranean Basin, were trained in Paris, then dispatched to other parts of the Mediterranean. ${ }^{46}$ Their network of schools further expanded in countries under French colonial rule, with the exception of Algeria, where, from 1870, Jews were French citizens and often attended state schools. English competed with French, especially in Egypt and Iraq which were under British colonial rule. At the Shammash high school in Baghdad, the language of instruction was English, though the Alliance schools continued to offer a French education and attract students. ${ }^{47}$ Education in European languages not only highlighted differences between Jews and non-Jews, but also sharpened generational divisions within Jewish communities, and transformed gender relations at home and in society.

The Alliance is sometimes blamed for sowing divisions between Muslims and Jews, or for being an instrument of imperialism because it was attached to or identified with the language or culture of dominant colonial powers. ${ }^{48}$ Yet in places of French colonial rule, the French language also became asso-

erature, 26, 45-48; Joseph Chetrit, "Moda'ut hadashah la-anonomaliyut ve-le-lashonnișanehah shel tenu'at hasqala be-Maroqo be-sof ha-me'a ha-19," Miqqedem Umiyyam 2 (1986): 129-168; idem, "Haskala hébraique et haskala judéo-arabe à Tunis à la fin du XIX siècle," Entre orient et occident: Juifs et Musulmans en Tunisie (Paris: Éditions de l'éclat, 2007), 289-320; Joseph Chetrit, "La question linguistique dans la presse judéo-arabe de Tunis à la fin du XIX siècle," in Claude Nataf (ed.), De Tunis à Paris: Mélanges à la mémoire de Paul Sebag (Paris: Éditions de l'éclat, 2008), 47-71.

44 For the influence of French on Judeo-Arabic, the hybridization of Jewish languages, and the development of bilingualism in North Africa, see Joseph Chetrit, "L'influence du français dans les langues judéo-arabes d'Afrique du Nord," in Judä̈sme d'Afrique du Nord aux xixe-xxe siècles: Histoire, société et culture (Jerusalem: Institut Ben-Zvi, 1980), 125-159; for a case study of Meknes, see idem, Diglossie, hybridation et diversité intra-linguistique: Études socio-pragmatique sur les langues juives, le judéo-Arabe et le judéo-berbère (Paris: Éditions Peeters, 2007), 431-46o.

45 Michael M. Laskier, The Alliance Israélite Universelle and the Jewish Communities of Morocco, 1862-1962 (Albany: State University of New York Press, 1983).

46 Rodrigue, Jews and Muslims; Frances Malino, "Institutrices in the Metropole and the Maghreb: A Comparative Perspective," Historical Reflections 32, 1 (2006): 129-142.

47 Bashkin, New Babylonians, 80-81.

48 Abitbol, Le passé d'une discorde, 220-228. 
ciated with the "modern," public sector to which Muslims might also aspire. Under colonial rule, French became a vehicle for advancement. It is certain that Jews saw the value of modern education in a European language, and in the language of the colonizer, which, as a minority they realized could give them an edge over Muslims; ${ }^{49}$ the gap between French-educated Jews and Muslims was also noticed and commented on by Muslim intellectuals. Even more radically, education for women in European languages was seen as a way to acquire Western ways and manners, which was important for the marriage market or for new forms of work and sociability in public spaces that were transforming gender roles. Jewish girls, along with boys, acquired modern education in various kinds of schools, not only of the Alliance Israélite Universelle, but also in state schools, as in Algeria and Iraq, Italian schools in Libya, or Christian and missionary schools, as was the case in Egypt. Jewish women also acquired vocational skills in schools, which they used in their expanding public roles in the workplace..$^{50}$ If Muslim nationalists criticized the willingness of Jews to attend French and other foreign schools, it was also recognized that Jews were conduits of modernity that was facilitated by modern education in European languages, and for some Muslims, this may have provided a model or incentive to also become modern and even address the question of changing gender roles. ${ }^{51}$ In some places in Egypt, Iraq, and Morocco, Muslims, though in small numbers, enrolled in AIU schools. ${ }^{52}$ French education was also seen by Muslims as important cultural capital in Egypt, as it was the lingua franca of the business community from the late nineteenth century on and was essential for working in the private economic sector. In Egypt, therefore, Muslims attended French schools, including Christian missionary schools together with Egyptian Christians and Jews. ${ }^{53}$ The gap in the modern literacy of Jewish men and women

49 Sara Reguer, "The World of Women," in The Jews of the Middle East, 242-243; Reeva Spector Simon, "Europe in the Middle East," in The Jews of the Middle East, 24; Keith Walters, "Education for Jewish Girls in Late Nineteenth- and Early Twentieth-Century Tunis and the Spread of French in Tunisia," in Emily Benichou Gottreich and Daniel J. Schroeter (eds.), Jewish Culture and Society in North Africa (Bloomington: Indiana University Press, 2011), 270-271.

5o Rachel Simon, Change within Tradition among Jewish Women in Libya (Seattle: University of Washington Press, 1992), 99-102, 111-153; Krämer, Jews in Modern Egypt, 38, 80-81, 91, 192.

$51 \quad$ Walters, "Education for Jewish Girls," 278.

$5^{2}$ In Tanta, Egypt, for example: Krämer, Jews in Modern Egypt, 111.

53 Frédéric Abécassis, "L'enseignement du français en Egypte dans les années 1920: une nébuleuse à plusieurs degrés de francité." Documents pour l'histoire du français langue 
relative to the Muslim population accelerated under colonial rule, but did not, however, cause Muslims to reject the advantages of a modern, European education, but rather, to decry the growing disparity between Muslims and Jews.

Although Muslims and Jews became increasingly divided politically during the course of the twentieth century, the educated elite and intelligentsia of both communities participated and communicated in new forms of public discourse, in the writing and publication of newspapers and books, and by engaging in debates in the public sphere. While in most Arabic-speaking regions, local Jewish dialects remained, the status of Judeo-Arabic as the communal language was challenged by modern education. Judeo-Arabic was modernized in places, as newspapers and the printing press began to publish works. A similar observation could be made of Judeo-Spanish. In colonial North Africa, French language newspapers were becoming the official organs of the Jewish communities. Alongside Jewish languages, European languages became public languages, with the multiplication of newspapers of various political persuasions. ${ }^{54}$ Jewish-owned newspapers in French engaged in debate with Muslims who also wrote in French-language newspapers.

For Jews in Egypt and especially Iraq, modern Arabic was also a public language of the Jews. Historically, literary Arabic written in Arabic script had rarely been the language of the Jews. This exclusion of the Jews from a modern Arabic education was perpetuated during colonial rule in the Maghrib, because the French were anxious to maintain the distinctions between ethnoreligious groups, while the Jews saw European languages as "modern," and Jewish schools paid little or no attention to Arabic. It was only after independence in Morocco, when the Alliance became known locally as the Ittihad Maroc and was partially subsidized by the Moroccan government, that the Arabic curriculum was mandated by the government and integrated into the Jewish educational system. ${ }^{55}$ The situation in the Arab Mashriq, or East, was somewhat different. As Arabic speakers redefined their identities amid the rapid changes in the late Ottoman period, a number of Jews participated in the nahda, the renaissance of Arabic letters, and were educated in Arabic in Beirut and Cairo. Arabic was taught in the Alliance schools in the Arab Middle East, especially Iraq.

étrangère ou seconde 27 (2001): 97-114; idem, "Approche d'un champ: l'enseignement étranger en Égypte, d'après la statistique scolaire de l'Égypte, 1921-1951," Égypte/Monde arabe, Première série, 18-19 (1994): 169-196; Beinin, The Dispersion of Egyptian Jewry, 50.

For an excellent overview of the Jewish press in MENA, see Rachel Simon, "Journalism," EJIW, 3:33-39. 
In polyglot Egypt, with perhaps the most diverse community of the Middle East, a result of waves of immigration from the late nineteenth century, Arabic competed with a multitude of languages used by educated Jews-French, Italian, Ladino, etc. Italian and then increasingly French were the main languages of the communal or Jewish schools. English gained headway from 1882, following the British occupation of Egypt. With the plethora of communal, Christian, and missionary schools that Jews attended, Arabic began to lose ground as the spoken language of the educated, but remained dominant among the Karaites and poorer Jews of Cairo and provincial towns. ${ }^{56}$

However, as the nationalist movement gained momentum in the interwar years-the British granted nominal independence in 1922, though they maintained the upper hand in Egypt for many years-literary Arabic lingered on as some Jews participated in the growing Arab public sphere in Egypt. The example of the last Arabic language Jewish newspaper, al-Shams (published from 1934 to 1938), is indicative of this participation in the public sphere. The owner and editor of the newspaper, Sa ${ }^{c}$ Y Ya'qūb Malkī, used the newspaper as a vehicle to represent the Jewish community to the Egyptian public and government; he supported an Egyptian reformist agenda as well as Zionism while emphasizing the adoption of Arabic by the Jewish community and integration into Egyptian society. ${ }^{57}$ Some Jewish intellectuals, political activists, and community leaders sometimes supported both Zionism and Egyptian nationalism or joined the nationalist Wafd party. ${ }^{58}$

The increasingly contradictory agenda of supporting both Zionism and Arab nationalism demonstrates not only the mounting tensions between Muslims and Jews, but also underscored Jewish participation in the public sphere and in political space that would have been unimaginable in the nineteenth century. With the notable exception of Iraq, Jews remained largely on the sidelines of nationalist politics in MENA, uncertain of their future and in some places, alienated by the Islamist reformist agenda of the nationalist and independence movements. Further complicating their participation was the conflict in Palestine and the increasing linkage, real or imagined, of Jews to Zionism. Yet we can also note that the level of participation in nationalist politics by the population as a whole remained limited, and in some spheres of political life Jews

\footnotetext{
$56 \quad$ Krämer, The Jews in Modern Egypt, 26-29.

57 Lital Levy, "al-Shams," EJIW, 4:341-342.

$5^{8}$ Ruth Kimche, Șiyonut be-șel ha-piramidot: ha-tenu'ah ha-șiyonit be-Mișrayim, 1918-1948 (Tel Aviv: Am Oved, 2009), 28-30, 166-169; Krämer, Jews in Modern Egypt, 28; Beinin, The Dispersion of Egyptian Jewry, 33-35, 46 .
} 
participated disproportionately to their numbers. Take, for example, the case of communism, a kind of secular middle ground, where in theory one's religious background is irrelevant. In Iraq, Egypt, and Tunisia Jews were very active in communist parties, and in Egypt and Tunisia in particular, were among some of its founders and leaders. ${ }^{59}$

Some Jews went further than the rejection of Zionism that was characteristic of communist parties; in Iraq in 1945, Jewish communists were the leaders and founders of the anti-Zionist political organization, the League for Combating Zionism, and its journal, al-'Usba (The league). ${ }^{60}$ In Morocco, on the eve of independence, Jews joined Muslims in forming a new organization, alWifaq, which announced in the main hall of the Chamber of Commerce in Casablanca, their expression of national unity and solidarity regardless of religion; in 1956, al-Wifaq denounced the French, British, and Israeli aggression against Egypt, and disseminated its statement to the public in Judeo-Arabic, Arabic, and French, symbolically representing the communal languages of each religious community respectively, while French represented the modern public language shared by Muslims and Jews. ${ }^{61}$

Even in the participation of Jews in Zionist parties, especially those active in Egypt and Tunisia in the interwar years, the very debates and denunciations that Zionist activism engendered, not only between Muslims and Jews but also internally within the Jewish community, demonstrated the extent to which Jews and Muslims had become a part of a common public sphere. Polemics and debates, for example, were exchanged in 1948 between an Arabic daily newspaper, al-Nahda and a French Jewish daily, Le Petit Matin, over the question of the inclusion of Jews in the civil service in Tunisia; the polemics were exacerbated by the Israeli-Arab conflict. ${ }^{62}$ This is not to deny that Zionism eventually

59 Bashkin, New Babylonians, 141-161, 179-182; Habib Kazdaghli, Tațawwur al-haraka al-Shuyūịyya bi-Tūnis, 1919-1943 (Manūba: Manshūrāt Kulīyat al-Ādāb, Jāmi'at Tūnis, 1992); Irmgard Schrand, Jews in Egypt: Communists and Citizens (Münster: Lit Verlag, 2004); Beinin, The Dispersion of Egyptian Jewry, 142-148.

6o Bashkin, New Babylonians, 161-177.

61 On al-Wifaq, see Mohammed Hatmi, "al-Jāmācat al-yahūdiya al-maghribīya wa-al-khiyār al-sa 'b bayn nidā’ al-ṣahyūniya wa-rihān al-Maghrib al-mustiqill: 1947-1961” (state doctoral diss., Université Sidi Mohamed Ben Abdellah-Fès, 2007), 429-435; Mohammad Kenbib, "al-Wifāq," EJIW 4:608; Boum, Memoires of Absence, 114-115. Thanks to Paul Dahan, President of the Centre de la Culture Judéo-Marocaine (Bruxelles) for giving me a copy of this declaration.

62 Mohsen Hamli, "The 1948 Controversy over the Accession of Jews to the Caïdal Corps in Tunisia," Journal of North African Studies 11, no. 4 (2006): 435-445. 
became irreconcilable to the Arab public, and indeed was eventually banned in independent Arab states, but if we think of the public sphere as a space where political opinion can be formed and debated, then Zionist politics was as much a part of the public, political realm as Jews joining forces with Muslims in communist movements, labor unions, or nationalist parties.

To the extent that one thinks of the public sphere as political space, Iraq in the interwar years offers the most striking example of a developing common ground. Despite the multi-ethnic sectarianism, perhaps more pronounced than anywhere else in the Arabic-speaking world, there was also a thriving, nonsectarian nationalism in Iraq, where Jews articulated an identity in the Arab public sphere. ${ }^{63}$ Iraq was unique in the sense that most Jews there were citizens of an independent Arab nation state, were educated in modern Arabic in their communal schools, attended state secondary schools in disproportionate numbers, were actively engaged in the Arabic-language press, letters, and arts, and worked in various public institutions. Jews published newspapers in Arabic, notably al-Mișbāh and al-Hāssid, that also had Muslims contributors, while some Jewish authors, feeling a part of the larger pan-Arab issues, also published articles in Egyptian and Lebanese newspapers. ${ }^{64}$ A growing number of Jews participated in and supported both Iraqi and pan-Arab nationalism; they were clearly staking their future as citizens of an independent Iraq and defining themselves as Arabs. Even in the 1940s, as tensions grew over the issue of Palestine, a larger than ever Jewish public was being educated in Arabic and participating in the Iraqi and Arab public sphere.

Iraq was, in many respects, a unique case, but it also raises "what if" questions about other parts of MENA. It is no coincidence that mainly among members of the Iraqi Jewish diaspora, including second-generation immigrants, the term "Arab Jews" is used to describe the Jews of Arab lands and in this manner they assign an identity for contemporary political reasons that did not exist in most places in the past, at least in the way Jews represented themselves. ${ }^{65}$ Yet Iraq, with the partial exception of Egypt, presents a somewhat different picture than the ideational construct of the Arab Jew. Nowhere else were there so many Jews involved in the modern nationalist project. And in Egypt, with its very hybrid cosmopolitan Jewish population, many Jews did

63 Bashkin, New Babylonians, 6-7.

64 Ibid., 24-37.

65 See Lital Levy, "Historicizing the Concept of Arab Jews in the Mashriq," Jewish Quarterly Review 98, 4 (2008): 452-469; Emily Benichou Gottreich, "Historicizing the Concept of Arab Jews in the Maghrib," Jewish Quarterly Review 98, 4 (2008): 433-451. 
not become Egyptian citizens. No more than 10,000 of Egypt's 80,000 Jews held Egyptian citizenship, about half were stateless, while 30,00o were citizens of foreign states. The secular-liberal ideology that accompanied the 1919 nationalist uprising that promoted citizenship for all attracted some Jews to become citizens, but Egyptian independence in 1922 was limited by the continued British presence and maintenance of European privileges. The perpetuation of communal courts, and the continuation of mixed courts where foreign citizens still retained the right to adjudicate, helped preserve the legal divisions and separations that worked against the fuller membership of Jews in the Egyptian nation. ${ }^{66} \mathrm{Had}$ there been a similar experience of living as full citizens in an independent Arab country as there was in the interwar years in Iraq, perhaps Jews elsewhere might have become a part of the Arab public sphere. By the time the Maghrib had achieved independence and ended colonial rule, the state of Israel was born and the age of mass emigration had already begun.

If colonialism in the Maghrib precluded the possibility of Jews becoming a part of an Arab public sphere or identifying themselves as Arabs and members of Arab nations, it did not prevent the development of a public sphere where Jews and Muslims participated in a common Arab cultural milieu. Perhaps the best example of this is in the world of MENA music, certainly an important space that could transcend religious and ethnic boundaries. Before modern times, music making and performance functioned as a kind of special common ground for Muslim-Jewish interaction. In many places in MENA Jewish musicians were disproportionate in numbers to their Muslim counterparts. While Jews made music for the internal communal world and in communal languages, such as for the liturgy in synagogues, they also produced and performed music of many different local genres for Muslim patrons, in palaces and the homes of the wealthy, and in coffeehouses throughout the Ottoman Empire, which reached a public beyond the elite. Orchestras and musical ensembles were also sometimes mixed, with Muslim and Jewish musicians performing together. Essaouira, for example, was known for its Jewish performers and artists, but also had mixed ensembles that played for Muslims and Jews in the public sphere. Ironically, this shared space of "Judeo-Arab" music as it is still called in France today reached its apogee in the colonial era. Modernity and the public sphere under colonial rule greatly expanded the spaces and venues for musical performance and production, both instrumental and vocal, and also contributed to the development of new genres. 
Muslims and Jews participated on common ground, not only in the cafés, nightclubs, concert and dance halls, and weddings, but in the development of a recording industry, film industry, and in radio broadcasting. ${ }^{67}$ In Iraq, Salāh al-Kuwaytī launched a modern school of Arabic music, and together with his brother Dāūd helped develop the national Iraqi Radio Orchestra, which was broadcast from the royal palace in the $1930{ }^{68}{ }^{6}$ In Algeria especially, the collaboration of Muslims and Jews was crucial for the preservation of a common cultural heritage; new styles developed from the cross-fertilization of music across the Mediterranean, and were performed and recorded in the many new public spaces. ${ }^{69}$

Yet the expanding public realm of musical performance and production also, like politics, produced tensions between Muslims and Jews. This was perhaps most poignantly expressed by the 1961 assassination in Constantine of Cheikh Raymond Leyris, the dominant figure in the Algerian music scene. The common Muslim-Jewish performance and production of music remains a subject of memory long after the period of mass emigration, not only in MENA, but in the contested spaces among emigrant communities, both Muslim and Jewish, from France to Israel. ${ }^{70}$

Nowhere is this more evident - to return, so to speak, to my place of originthan in Essaouira. Long in decline, dilapidated, and rarely the destination of tourists, it has in recent years been revived by the massive annual Gnawa music festival and in new hotels along the beachfront and traditional houses converted into hotels (riads, riya a ds) within the walled town, often in homes of the casbah formerly owned by wealthy Jews accommodating the many visitors. The new tolerance, represented by the blending of African, Moroccan, and world music at the festival, is promoted alongside the official and more elitist representation of the Convivencia expressed in the common Muslim-Jewish heritage of the Andalusian and North African musical tradition, that was much a part of the town in the era when there was a thriving Jewish community, and

\footnotetext{
67 Edwin Seroussi, "Music," EJIW, 3:501-519.

68 Edwin Serousi, "Salah and Daud al-Kuweiti," EJIW, 3:194-195.

69 Hadj Miliani, "Crosscurrents: Trajectories of Algerian Jewish Artists and Men of Culture since the End of the Nineteenth Century," in Jewish Culture and Society in North Africa, 177-187.

70 Hisham D. Aidi, Rebel Music: Race, Empire, and the New Muslim Youth Culture (New York: Pantheon Books, 2014), 260-261, 281-289; Ted Swedenburg, "Against Hybridity: The Case of Enrico Macias/Gaston Ghrenassia," in Rebecca L. Stein and Ted Swedenburg (eds.), Palestine, Israel, and the Politics of Popular Culture (Durham, NC: Duke University Press, 2005), 231-256, 328-334.
} 
since 2003 publicly celebrated in the Festival des Andalousies Atlantiques. ${ }^{71}$ During the much more massive and popular Gnawa festival—-the "Moroccan Woodstock" as some have called it ${ }^{72}$ — the Judeo-Arab musical tradition takes a back seat, relegated to lectures for small audiences in the riya âds, as the sounds of the rhythmic, stringed gumbri and chants of the Afro-Moroccan Gnawa performers waft through the streets of the casbah from the stage set up at the square where Mr. Hatchwell, already in 1981 the remnant of a bygone age, once owned his modest hotel.

\section{Bibliography}

Abdel Nour, Antoine. "Habitat et structures sociales à Alep aux XVII et XVIII ${ }^{\mathrm{e}}$ siècles." In Abdelwahab Bouhdiba and Dominique Chevalier (eds.), La ville arabe dans l'Islam. La ville arabe dans l'Islam, 69-102. Tunis: Université de Tunis, Centre d'études et de recherches économiques et sociales, 1982.

Abécassis, Frédéric. "Approche d'un champ: l'enseignement étranger en Égypte, d' après la statistique scolaire de l'Égypte, 1921-1951." Égypte/Monde arabe, Première série 18-19 (1994): 169-196.

"'L'enseignement du français en Egypte dans les années 1920: une nébuleuse à plusieurs degrés de francité." Documents pour l'histoire du français langue étrangère ou seconde 27 (2001): 97-114.

Abitbol, Michel. Le passé d'une discorde:Juifs et Arabes depuis le viie siècle. Paris: Perrin, 1999 .

Aidi, Hisham D. Rebel Music:Race, Empire, and the New Muslim Youth Culture. New York: Pantheon Books, 2014.

Bahloul, Joëlle. The Architecture of Memory: A Jewish-Muslim Household in Colonial Algeria, 1937-1962. Cambridge: Cambridge University Press, 1996.

Bashkin, Orit. New Babylonians: A History ofJews in Modern Iraq. Stanford, CA: Stanford University Press, 2012.

Bat Ye'or. The Dhimmi:Jews and Christians under Islam. Rutherford, NJ: Fairleigh Dickinson University Press; London: Associated University Presses, 1985.

Islam and Dhimmitude: Where Civilizations Collide. Cranbury, NJ: Fairleigh Dickinson University Press/Associated University Presses and Lancaster, UK: Gazelle Book Services Ltd., 2002.

71 Aomar Boum, "The Performance of Convivencia: Communities of Tolerance and the Reification of Toleration," Religion Compass 6, no. 3 (2012): 180-182.

72 Aidi, Rebel Music, 145-146, 148, $15^{2}$. 
Beinin, Joel. The Dispersion of Egyptian Jewry: Culture, Politics, and the Formation of a Modern Diaspora. Berkeley: University of California Press, 1998.

Bensoussan, David. Le fils de Mogador. Montreal: Les Éditions Du Lys, 2002.

Bensoussan, Georges. Juifs en pays arabes: le grand déracinement, 1850-1975. Paris: Tallandier, 2012.

Boum, Aomar. Memories of Absence: How Muslims Remember Jews in Morocco. Stanford, CA: Stanford University Press, 2013.

"The Performance of Convivencia: Communities of Tolerance and the Reification of Toleration." Religion Compass 6, no. 3 (2012):180-196.

Chetrit, Joseph. Diglossie, hybridation et diversité intra-linguistique: Études socio-pragmatique sur les langues juives, le judéo-Arabe et le judéo-berbère. Paris: Éditions Peeters, 2007.

. "Haskala hébraique et haskala judéo-arabe à Tunis à la fin du XIX ${ }^{\mathrm{e}}$ siècle." In Entre orient et occident: Juifs et Musulmans en Tunisie, 289-320. Paris: Éditions de l'éclat, 2007.

"L'influence du français dans les langues judéo-arabes d'Afrique du Nord." In Michel Abitbol (ed.), Judä̈sme d'Afrique du Nord aux xix ${ }^{e}-x x^{e}$ siècles: Histoire, société et culture, 125-159. Jerusalem: Institut Ben-Zvi, 1980.

. "Modacut hadashah la-anonomaliyut ve-le-lashon—niṣanehah shel tenu'at hasqala be-Maroqo be-sof ha-me’a ha-19." Miqqedem Umiyyam 2 (1986): 129-168.

. "La question linguistique dans la presse judéo-arabe de Tunis à la fin du XIX" siècle." In Claude Nataf (ed.) De Tunis à Paris: Mélanges à la mémoire de Paul Sebag, 47-71. Paris: Éditions de l' éclat, 2008.

Clancy-Smith, Julia A. Mediterraneans: North Africa and Europe in an Age of Migration, c. 1800-190o. Berkeley: University of California Press, 2011.

Cohen, Amnon. Jewish Life under Islam:Jerusalem in the Sixteenth Century. Cambridge, MA: Harvard University Press, 1984.

Cohen, Julia Phillips. Becoming Ottomans: SephardiJews and Imperial Citizenship in the Modern Era. New York: Oxford University Press, 2014.

Cohen, Mark R. Under Crescent and Cross: The Jews in the Middle Ages. Princeton, NJ: Princeton University Press, 1994.

Deshen, Shlomo. "Baghdad Jewry in Late Ottoman Times: The Emergence of Social Classes and of Secularization." AJs Review 19, no. 1 (1994): 37-40.

Dicale, Bertand. Cheikh Raymond: Un histoire algérienne. Paris: Éditions First-Gründ, 2011.

Eickelman, Dale F. "Islam and the Languages of Modernity." Daedalus 129, no. 1 (2000): 119-135.

and Armando Salvatore. "The Public Sphere and Muslim Identities." European Journal of Sociology 43 (2002): 92-115.

Eisenstadt, S.N. "Multiple Modernities." Daedalus 129, no. 1 (2000): 1-29. 
Eraqi-Klorman, Bat-Zion. "Yemen: Religion, Magic, and Jews." Proceedings of the Seminar for Arabian Studies 39 (2009): 125-134.

Gerber, Haim. "The Public Sphere and Civil Society in the Ottoman Empire." In Miriam Hoexter, Shmuel N. Eisenstadt, and Nehemia Levtzion (eds.), The Public Sphere in Muslim Societies, 65-82. Albany: State University of New York Press, 2002.

Geertz, Clifford. "Suq: the Bazaar Economy in Sefrou." In Clifford Geertz, Hildred Geertz, and Lawrence Rosen, Meaning and Order in Moroccan Society, 123-244. Cambridge: Cambridge University Press, 1979.

Goldberg, Harvey E. Jewish Life in Muslim Libya: Rivals and Relatives. Chicago: University of Chicago Press, 1990.

and Claudio G. Segre. "Holding on to Both Ends: Religious Continuity and Change in the Libya Jewish Community, 1860-1949." Maghreb Review 14, nos. 3-4 (1989): 161-186.

Gottreich, Emily Benichou. "Historicizing the Concept of Arab Jews in the Maghrib." Jewish Quarterly Review 98, no. 4 (2008): 433-451.

. The Mellah of Marrakesh: Jewish and Muslim Space in Morocco's Red City. Bloomington: Indiana University Press, 2007.

Green, Abigail. Moses Montefiore:Jewish Liberator, Imperial Hero. Cambridge, MA: Belknap Press of Harvard University Press, 2010.

Grehan, James. Everyday Life and Consumer Culture in 18th-Century Damascus. Seattle: University of Washington Press, 2007.

Guillen, Pierre. L'Allemagne et le Maroc de 1870 à 1905. Paris: Presses universitaires de France, 1967 .

Hakim, Besim Selim. Arabic-Islamic Cities: Building and Planning Principles. London: KPI, 1986.

Hamli, Mohsen. "The 1948 Controversy over the Accession of Jews to the Caïdal Corps in Tunisia." Journal of North African Studies 11, no. 4 (2006): 435-445.

Hatmi, Mohammed. "al-Jāmā'at al-yahūdiya al-maghribīya wa-al-khiyār al-sacb bayn nidā' al-ṣahyūniya wa-rihān al-Maghrib al-mustiqill: 1947-1961." State doctoral dissertation, Université Sidi Mohamed Ben Abdellah-Fès, 2007.

Hattox, Ralph S. Coffee and Coffeehouses: The Origins of a Social Beverage in the Medieval Near East. Seattle: University of Washington Press, 1985.

Kazdaghli, Habib. Tațawwur al-ḥaraka al-Shuyūịyya bi-Tūnis, 1919-1943. Manūba: Manshūrāt Kulīyat al-Ādāb, Jāmi'at Tūnis, 1992.

Kenbib, Mohammed. Juifs et Musulmans au Maroc, 1859-1948. Rabat: Université Mohammed v, Publications de la Faculté des Lettres et des Sciences Humaines, 1994.

- "al-Wifāq." EJIW, 4:608.

Kimche, Ruth. Șiyonut be-șel ha-piramidot: ha-tenu'ah ha-șiyonit be-Mișrayim, 1918-1948. Tel Aviv: Am Oved, 2009. 
Knafo, Salomon Haï and Asher Knafo, La vie juive a Mogador. Ashdod: Ot Brit Kodech, 2009.

Krämer, Gudrun. The Jews in Modern Egypt, 1915-1952. Seattle: University of Washington Press, 1989 .

Larguèche, Abdelhamid. "La communauté juive de Tunis à l'époque husseïnite: unité, contrastes et relations inter-communautaires." In Histoire communautaire, histoire plurielle: la communauté juive de Tunisie: actes du colloque de Tunis organisé les 2526-27 février 1998 à la Faculté de la Manouba, 165-180. Tunis: Centre de Publication Universitaire, 1999.

Laskier, Michael M. The Alliance Israélite Universelle and the Jewish Communities of Morocco, 1862-1962. Albany: State University of New York Press, 1983.

and Reeva Spector Simon. "Economic Life." In Reeva Spector Simon, Michael Menachem Laskier, and Sara Reguer (eds.), The Jews of the Middle East and North Africa in Modern Times, 29-48. New York: Columbia University Press, 2003.

Lehmann, Matthias B. Ladino Rabbinic Literature and Ottoman Sephardic Culture Bloomington: Indiana University Press, 2005.

Levy, Lital. "Historicizing the Concept of Arab Jews in the Mashriq." Jewish Quarterly Review 98, 4 (2008): 452-469.

_ . "Self and the City: Literary Representations of Jewish Baghdad." Prooftexts 26 , nos. 1-2 (2006): 163-211.

- "al-Shams." EJIW, 4:341-342.

Lewis, Bernard. The Jews of Islam. Princeton: Princeton University Press, 1984. Semites and Anti-Semites. New York: Norton, 1986.

Malino, Frances. "Institutrices in the Metropole and the Maghreb: A Comparative Perspective." Historical Reflections 32, no. 1 (2006): 129-142.

Marcus, Abraham. The Middle East on the Eve of Modernity: Aleppo in the Eighteenth Century. New York: Columbia University Press, 1989.

Marglin, Jessica. "In the Courts of the Nations: Jews, Muslims, and Legal Pluralism in Nineteenth-Century Morocco." PhD dissertation, Princeton University, 2013.

Masters, Bruce. Christians and Jews in the Ottoman Arab World: The Roots of Sectarianism. Cambridge: Cambridge University Press, 2001.

Mikhail, Alain. "The Heart's Desire: Gender, Urban Space and the Ottoman Coffee House." In Dana Sajdi (ed.) Ottoman Tulips, Ottoman Coffee: Leisure and Lifestyle in the Eighteenth Century, 133-170. London: Tauris Academic Studies, 2007.

Miliani, Hadj. "Crosscurrents: Trajectories of Algerian Jewish Artists and Men of Culture since the End of the Nineteenth Century." In Emily Benichou Gottreich and Daniel J. Schroeter (eds.), Jewish Culture and Society in North Africa, 177-187. Bloomington: Indiana University Press, 2011.

Miller, Susan Gilson. "Kippur on the Amazon: Jewish Emigration from Northern Morocco in the Late Nineteenth Century." In Harvey E. Goldberg (ed.), Sephardi and 
Middle Eastern Jewries, History and Culture in the Modern Era, 190-209. Bloomington: Indiana University Press, 1996. and Mauro Bertagnin (eds.). The Architecture and Memory of the Minority Quarter in the Muslim Mediterranean City. Cambridge, MA: The Aga Khan Program at the Harvard University Graduate School of Design, 2010.

al-Nāṣirī, Aḥmad b Khālid. Kitāb al-Istiqșā li-akhbār duwal al-Maghrib al-aqșā. Casablanca: Dār al-Kitāb, $195^{6 .}$

al-Qattan, Najwa. "Litigants and Neighbors: The Communal Topography of Ottoman Damascus." Comparative Studies in Society and History 44 (2002): 511-533.

Quataert, Donald. The Ottoman Empire, 1700-1922. Cambridge: Cambridge University Press, 2000.

Raymond, André. Grandes villes arabes à l'époque ottomane. Paris: Sindbad, 1985.

Reguer, Sara. "The World of Women." In Reeva Spector Simon, Michael Menachem Laskier, and Sara Reguer (eds.), The Jews of the Middle East and North Africa in Modern Times, 235-250. New York: Columbia University Press, 2003.

Reynolds, Nancy Y. A City Consumed: Urban Commerce, the Cairo Fire, and the Politics of Decolonization in Egypt. Stanford, CA: Stanford University Press, 2012.

Rodrigue, Aron. French Jews, Turkish Jews: The Alliance Israelite Universelle and the Politics of Jewish Schooling in Turkey 1860-1925. Bloomington: Indiana University Press 1990.

- Jews and Muslims: Images of Sephardi and Eastern Jewries in Modern Times. Seattle: University of Washington Press, 2003.

Salvatore, Armando and Mark LeVine (eds.). Religion, Social Practice, and Contested Hegemonies:Reconstructing the Public Sphere in Muslim Majority Societies. New York: Palgrave MacMillan, 2005.

Schlaepfer, Aline. "Between Cultural and National Nahda: Jewish Intellectuals in Baghdad and the Nation-Building Process in Iraq." Journal of Levantine Studies 1, no. 2 (2011): 59-74.

Schrand, Irmgard. Jews in Egypt: Communists and Citizens. Münster: Lit Verlag, 2004. Schroeter, Daniel J. "The Jewish Quarter and the Moroccan City." In George K. Zucker and Yedida K. Stillman (eds.), New Horizons in Sephardic Studies, 67-81. Albany: State University of New York Press, 1993.

- Merchants of Essaouira: Urban Society and Imperialism in Southwestern Morocco, 1844-1886. Cambridge: Cambridge University Press, 1988.

"Le quartier juif et la cité islamique." In Shmuel Trigano (ed.), Le monde sépharade: histoire et civilisation, vol. 2, 565-583. Paris: Éditions du Seuil, 2006.

- "From Sephardi To Oriental: The 'Decline' Theory of Jewish Civilization in The Middle East and North Africa." In Richard Cohen and Jeremy Cohen (eds.), The Jewish Contribution to Civilization: Reassessing an Idea, 125-148. Oxford: Littman Library of Jewish Civilization, 2007. 
- The Sultan's Jew: Morocco and the Sephardi World. Stanford, ca: Stanford University Press, 2002.

"Trade as a Mediator in Muslim-Jewish Relations: Southwestern Morocco in the Nineteenth Century." In Mark R. Cohen and Abraham L. Udovitch (eds.), Jews Among Arabs: Contacts and Boundaries, 113-140. Princeton, NJ: Darwin Press, 1989 .

and Joseph Chetrit. "Emancipation and its Discontents: Jews at the Formative Period of Colonial Rule in Morocco." Jewish Social Studies 13, no. 1 (2006): 170-206.

Sebag, Paul. Histoire des Juifs de Tunisie: des origins à nos jours. Paris: L'Harmattan, 1991. Segal, Ariel. Jews of the Amazon: Self-Exile in Earthly Paradise. Philadelphia: Jewish Publication Society, 1999.

Seroussi, Edwin. “Music." EJIW, 3:501-519.

"Salah and Daud al-Kuweiti." EJIW, 3:194-195.

Simon, Rachel. Change within Tradition among Jewish Women in Libya. Seattle: University of Washington Press, 1992.

. "Journalism." EJIW, 3:33-39.

Simon, Reeva Spector. "Banking." EJIW, 1:335-337.

. "Europe in the Middle East." In Reeva Spector Simon, Michael Menachem Laskier, and Sara Reguer (eds.), The Jews of the Middle East and North Africa in Modern Times, 19-28. New York: Columbia University Press, 2003.

—. "Iraq." In Reeva Spector Simon, Michael Menachem Laskier, and Sara Reguer (eds.), The Jews of the Middle East and North Africa in Modern Times, 347-366. New York: Columbia University Press, 2003.

Stein, Sarah Abrevaya. MakingJews Modern: The Yiddish and Ladino Press in the Russian and Ottoman Empires. Bloomington: Indiana University Press, 2004.

Stillman, Norman A. The Jews of Arab Lands in Modern Times. Philadelphia: Jewish Publication Society, 1991.

Stora, Benjamin. Les trois exils Juifs d'Algérie. Paris: Éditions Stock, 2006.

Swedenburg, Ted. "Against Hybridity: The Case of Enrico Macias/Gaston Ghrenassia." In Rebecca L. Stein and Ted Swedenburg (eds.), Palestine, Israel, and the Politics of Popular Culture, 120-140. Durham, NC: Duke University Press, 2005.

Tsadik, Daniel. Between Foreigners and Shicis: Nineteenth-Century Iran and its Jewish Minority. Stanford, CA: Stanford University Press, 2007.

Tsur, Yaron. "Ahd al-Amān." EJIW, 1:93-94.

Udovitch, Abraham L. and Lucette Valensi. The Last Arab Jews: The Communities of Jerba, Tunisia. Chur, Switzerland: Harwood Academic, 1984.

Walters, Keith. "Education for Jewish Girls in Late Nineteenth- and Early TwentiethCentury Tunis and the Spread of French in Tunisia." In Emily Benichou Gottreich and Daniel J. Schroeter (eds.), Jewish Culture and Society in North Africa, 257-281. Bloomington: Indiana University Press, 2011. 
Wirth, Eugen. "Villes islamiques, villes orientales? Une problematique face au changement." In Abdelwahab Bouhdiba and Dominique Chevalier (eds.), La ville arabe dans l'Islam, 198-226. Tunis: Université de Tunis, Centre d'études et de recherches économiques et sociales, 1982.

Zenner, Walter P. "Jews in Late Ottoman Syria: Community, Family and Religion." In Shlomo Deshen and Walter P. Zenner (eds.), Jews among Muslims: Communities in the Precolonial Middle East, 173-186. London: Macmillan, 1996.

Zohar, Zvi. Rabbinic Creativity in the Modern Middle East. London: Bloomsbury, 2013. 